\title{
1980 Financial Statement of the International Union of Geological Sciences and Budget for 1981
}

Statement of Receipts and Payments for the Year Ended December 31, 1980 (See Note 1)

\section{RECEIPTS}

- UNESCO contracts and receipts for IGCP projects

(See Note 2)

- Membership dues (See Note 3)

- Special grants and contracts (See Note 4)

- Allocation from UNESCO subvention to ICSU (See Note 5)

- Income from publications:

- EPISODES subscriptions and related income

- Royalties, IUGS Publications sales

- Bank interest and gain on exchange (See Note 6)

- Miscellaneous receipts

\section{PAYMENTS}

12000

8825

1467

4016

21092

TOTAL $\quad 309261$

1980

(\$U.S.)

111888

89600

33400

14000

12849

1410

2744

375

266266

- Scientific activities

- IGCP (See Note 7)

- IGCP: IUGS supplemental allocations

123026

4600

25708

26811

20021

5200

10000

17847

- Representation at meetings

- . Research Development Program

- Routine meetings

- 1979: Executive Committee meeting Zurich

- 1980: Executive Committee meeting, Mexico City

- 1980: Executive Committee meeting, Paris

- 1981: Executive Committee meeting, Accra (advanced payments)

- Publications

- EPISODES printing and related costs (See Note 10)

- IUGS new series publications: Ordovician correlation charts

- Administrative expenses

- Salaries and related charges

- Operating costs and supplies

- Miscellaneous charges

- Bank charges, loss on exchange

- Payments to ICSU

- 1977,1978 membership dues

- 1980 membership dues

- 1979 Contribution to Committee on Teaching of Science

- Dues to ICSU Abstracting Board

11114

15299

138075

7500

26921

21081

19060

14275

5000

3876

Budget

for

1981

(\$U.S.)

158600

140000

28000

9600

14000

1400

34000

385600

158000
8000
45000
10000
21100
10000
10000
20000

7025

8763

11435

20000

18322

1096

44000

10000

13439

7515

5692

522

18000

2845

4953

368

8000

4596

1925

300

360

TOTAL $\quad 275219$

312182

385600

Excess of income over expenditure

Excess of expenditure over income

Accumulated balance at January 1, 1980

Accumulated balance at December 31, 1980

Net financial assets at December 31, 1979

Net financial assets at December 31, 1980

34042

92997

127041

131368

127041

81125

113345

\section{STATUS OF ACCOUNTS}

December $31 \quad 1979$

Graz - Past Treasurer's account

Zurich - President's operations account

- Reserve account

Ottawa- Secretariat account

Ottawa - EPISODES account

Reston - Treasurer's account

\begin{tabular}{|c|c|c|}
\hline & $\begin{array}{r}3521 \\
467 \\
52692 \\
1139 \\
1 \quad 832 \\
67390 \\
\end{array}$ & \\
\hline TOTAL & 127041 & $\begin{array}{ll}73 & 495 \\
41 & 275 \\
32 & 220\end{array}$ \\
\hline 31,1980 & & 113345 \\
\hline
\end{tabular}

December 31, 1980

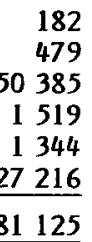

73495

1275

113345
Accounts receivable on December 31,1980

Accounts payable on December 31, 1980

Difference

NET FINANCIAL ASSETS AS OF DECEMBER 31, 1980

EPISODES, Vol. 1981, No. 3. 
Note 1

The Statement of Receipts and Payments and the Statement of Bank Balances of the IUGS for the year ended December, 1980, have been prepared by the Treasurer in accordance with the Statutes and Byelaws of the Union. Receipts and payments have been recorded in the books of account in the currency used by the bank account and then converted to \$U.S. at year-end based on official ICSU rates of exchange for December 31, 1980.

The Statements do not reflect:

a) costs borne by member countries in support of activities and operations of the Union;

b) details of unpaid accounts receivable or payable by the Union as at December 31, 1980.

In order to provide a basis for comparison, both the 1979 receipts and payments and the estimated income and projected expenditures for 1981 (under Budget for 1981) have been included.

\section{Note 2}

IGCP receipts come from one source: contract funds from UNESCO allocated to IGCP projects. Total payments to IGCP projects, however, include the following: the contract funds from UNESCO, an annual contribution from IUGS of $\$ 10000$ and the IUGS advances paid to projects to cover the $10 \%$ or $20 \%$ withheld by UNESCO until final reports and financial statements are submitted by IUGS. 1979 receipts figure includes $\$ 11700$ received for IGCP projects funded in 1978, while the 1980 figure includes $\$ 12538$ received for projects funded in 1979 (that is, final payments on contracts initiated in 1979). 1981 estimates assume that all amounts allocated by Unesco for IGCP projects in 1981 are received by IUGS during the year.

Note 3

Member countries pay annual contributions according to their selected category of membership as outlined in the following table:

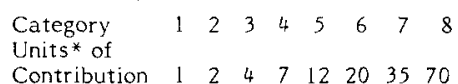

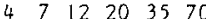

(*One unit of contribution was valued at U.S. $\$ 300$ as of July $10,1980$. .

The 1980 receipts figure includes $\$ 8600$ paid in 1980 covering membership dues for prior years.

Note 4

Receipts from special grants and contracts during 1980 consisted of:

COGEODATA contract with

CCOP/ESCAP No. CAP/79/01/

CAP/79/335

COGEODATA contract with

CCOP/ESCAP No./80/207/CON-01

Second Phase

15600

Supplemental grant from ICSU

under UNESCO contract 250.298

(final payment)

$$
\text { TOTAL } \frac{500}{33400}
$$

Note 5

IUGS receives $\$ 12000$ from ICSU as an apportioned amount of the UNESCO subvention to ICSU. IUGS pays an annual subvention to ICSU based on $2.5 \%$ of IUGS membership fees. IUGS paid a fixed annual contribution of $\$ 10000$ to ICG during its ten-year existence; for $1980, \$ 2000$ was allocated to ICG as a final subvention. The 1980 recelpts figure includes ICSU subventions for first and second instalments of 1980 grants.

Note 6

1980 receipts figure includes interest on accounts in Zurich plus $\$ 3052$ gained through change in value of Swiss currency relative to the U.S. dollars.

Note 7

1980 figure includes $\$ 22675$ in final payments on IGCP projects initiated in 1979.1981 figure shows total amounts payable on IGCP projects for 1981 only.
Note 8

Expenditures from special contracts during 1980 consisted of

ESCAP contract $80 / 207$

ESCAP contract CON/79/01/CAP/

79/335/01/CAP/79/335

UNESCO contract 250.298: Committee

on Geological Documentation

$$
\text { TOTAL } 21081
$$

Note 9

1980 figure includes expenditures for symposium on metallogenesis in Latin American held in Mexico City in February 1980 and advance payments to symposium on Precambrian of Africa held in Accra, Ghana in February 1981.

Note 10

1980 payments figure includes cost of printing 8000 copies of the Special Issue of EPISODES commem-

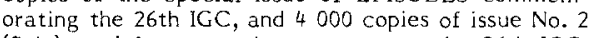
(July) used for promotion purposes at the 26th IGC. Budget figure for 1981 includes operations costs of EPISODES Secretariat and salaries, formerly reported under "administrative expenses".

\section{SCHEDULE A}

1980 PAYMENTS: COMMISSIONS, COMMITTEES

Commission on Marine Geology

Commission on Stratigraphy

Subcommission on Silurian

Stratigraphy

Subcommission on Devonian

Stratigraphy

Working Group on Paleogene/Neogene Boundary

Subcommission on Cretaceous

Stratigraphy

Subcommission on Jurassic

Stratigraphy

Subcommission on Neogene

Stratigraphy

Subcommission on Stratigraphic

Classification

Regional Committee on Neogene

Stratigraphy

Subcommission for the Stratigraphical

Lexicon

Subcommission on Cambrian

Stratigraphy

Subcommission on Ordovician

Stratigraphy

Working Group on Devonian-

Carboniferous Boundary

Subcommission on Gondwana

Stratigraphy

Subcommission on Paleogene

Stratigraphy

Working Group on Albion-Turonian

Stages

Working Group on Neogene-Quaternary

Boundary

Subcommission on Carboniferous

Stratigraphy

Subcommission on Precambrian

Stratigraphy

Working Group on Cambrian-

Ordovician Boundary

$\$ 6000$

2365

1300

1050

Commission on Experimental

Petrology

650

500

500

500

500

500

450

450

450

425

400

300

300

250

250

200

150

150

\section{COGEODATA}

Committee on the History of Geol. Sciences (INHIGEO)

Advisory Committee on Comparative

Plane tology

Advisory Board for Publication

$$
\text { TOTAL }
$$

Payments made in 1980 on 1979 allocations:

Commission on Tectonics

Subcommission for the

Stratigraphical Lexicon

Commission on Experimental Petrology

SCHEDULE B

1980 PAYMENTS: AFFILIATED ASSOCIATIONS

AGID

CGMW

INQUA

IAEG

IAH

IAGOD

IPA

SGA
IAP

IAGC

Editerra

3000

1500

1000

1000

825

600

600
500

500
400

250

TOTAL

14275

SCHEDULE A-81

1981 BUDGET: COMMISSIONS, COMMITTEES

Commission on Stratigraphy

Commission on Marine Geology

COGEODATA

Committee on Comparative

Planetology

Commission on Systematics in

Petrology

Commission on Tectonic

Exploratory Group on Geology as

related to Human Problems

Advisory Board for Publications

Committee on Geol. Documentation

ommittee on the History of Geol.

Sciences (INHIGEO)

$$
\text { TOTAL } \lcm{45000}
$$

21200

4000

2500

2000

2000

2000

1650

1400

SCHEDULE B-81

1981 BUDGET: AFFILIATED ASSOCIATIONS

AGID

CGMW

GSA

IAGOD

SGA

IAMC

IAEC

ICP

IPA

IAP

Editerra.

5000

4000

2550

2500

1500

1100

1000

1000

750
750

600

1500

350

TOTAL 21100

\section{sand texture sedimentology}

THE BEST TECHNIQUE -

MACROGRANOMETER - computerized high resolution high speed sedimentation balance for size and settling rate analyses of sand sized $(0.05-4 \mathrm{~mm})$ materials. 0.1 - 10 gram samples of sand;

Shape-specified PHIgrain-size \& PSFsettling-rate distributions, up to 317 \& 351 grades respectively; moments, mixed distribution parameters, etc.

- NEW SOLUTIONS IN:

Petroleum geology, basin analysis, tracing of (recent \& fossil) moving sand, sedimentology of placer (heavy mineral) deposits, stratigraphy, etc.

Contact us about:

- Analyzing for you (telexed results)

* Macrogranometer supply or renting

* Teaching \& personnel training program

Granometry

Heidelberger Str. 68

D-6903 Neckargemünd-3, West Germany

Phone (o)6223-1803 TX461201 grano

We are seeking U.S. representatives 


\section{Selected 7itles}

\section{The Primordial Bond}

\section{Exploring Connections between Man} and Nature through the Humanities and Sciences

by Stephen H. Bchneider and Lynne Morton

"The Primordial Bond illuminates the nature of the ecological crisis in terms familiar to the humanist... This well written book is a major contribution to the "two-cultures' dialogue advanced by C. P. Snow." -Paul R. Ehrlich, Stanford University 336 pp., illus., 1981, \$15.95 (\$19.14/£10.05 outside US)

\section{Ocean Dumping of}

\section{Industrial Wastes}

\section{edited by Bostwick H. Ketchum}

Woods Hole Oceanographic Institution, Massachusetts

Dana R. Kester

University of Rhode lsland

and P. Kilho Park

National Oceanic and Atmospheric Administration, Maryland

Ocean Dumping of Industrial Wastes presents a wealth of previously unpublished material. Specific chapters highlight hydrographic features and dispersion characteristics of wastes at US dumpsites, ocean disposal of wastes, and laboratory bioassay studies. Marine Science, Volume 12. 536 pp., illus., 1981, \$59.50 ( $\$ 71.40 / £ 37.49$ outside US)

\section{The Ocean Basins and Margins}

Volume 5

\section{The Arctic Ocean}

edited by Alan E. M. Nairn

University of South Carolina

Michael Churkin, Jr.

United States Geological Survey, California

and Francis G. Stehli

University of Florida

The Arctic Ocean, the fifth volume in the acclaimed series The Ocean Basins and Margins, gives a comprehensive account of present research on this controversial subject. Of special note is the presentation of a new geosynclinal theory, developed at the Geological lnstitute of the USSR Academy of Sciences. $686 \mathrm{pp}$., illus., $1981, \$ 55.00(\$ 66.00 / £ 34.65$ outside US $)$

\section{Biomass Conversion Processes for Energy and Fuels}

edited by $\mathbf{S a m i r} \mathbf{8}$. Sofer

University of Oklahoma

and Oskar R. Zaborsky

National Science Foundation

This work brings together in one volume a description of diverse elements of biomass sources, and some of the more promising conversion processes for energy and fuels. Specific topics addressed include silvicultural energy farms, gasification, and ethanol production by fermentation. approx. 450 pp., illus., 1981,

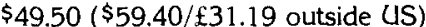

\section{Bottom-Interacting Ocean Acoustics}

edited by William A. Kuperman and Finn B. Jensen SACLANT ASW Research Centre, La Spezia, ltaly

This unique volume offers a broad overview of the field, as well as the latest techniques and tools of the trade. Topics include geoacoustic properties of marine sediments, bottom loss, bottominterface and seismic-wave propagation, and acoustic modelling. NATO Conference Series, Series IV: Marine Sciences, Volume 5. 730 pp., illus., 1981 , $\$ 75.00$ ( $\$ 90.00 / £ 47.25$ outside US)

\section{Surface Chemistry of Froth Flotation \\ by Jan Leja \\ University of British Columbia}

Surface Chemistry of Froth Flotation reviews the fundamentals of surface chemistry together with the relevant aspects of organic and inorganic chemistry that are important to the understanding and control of the froth flotation process. approx. 775 pp., illus., 1981, $\$ 69.50$ ( $\$ 83.40 / £ 43.79$ outside US)

\section{Skeletal Growth of Aquatic Organisms \\ Biological Records of Environmental Change}

edited by Donald C. Rhoads

Yale University

and Richard A. Lutz

Rutgers University

Investigating the dynamics of aquatic environments as preserved in the structural, morphological, and chemical changes in the skeletal parts of fossils and living organisms, this volume reflects the exciting new advances in bivalved mollusc and coral skeletal research in recent years. Topics in Geobiology. Volume 1.

764 pp., illus., $1980, \$ 47.50$ ( $\$ 57.00 / £ 29.93$ outside (IS)

\section{Introduction to Analytical Electron Microscopy}

edited by John J. Hren

University of Florida

Joseph I. Goldstein

Lehigh University

and David C. Joy

Bell Laboratories, Murray Hill, New Jersey

"... a complete review of the subject. ... All the authors are expert in their particular field, so that the numerous references are well selected and up to date."

- V. E. Cosslett, Nature 618 pp., $1979, \$ 35.00$ ( $\$ 42.00 / £ 22.05$ outside US)

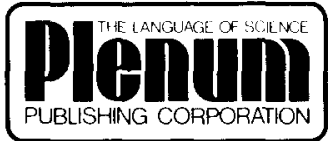

233 Spring Street, New York, N.Y. 10013

In United Kingdom: 88/90 Middlesex Street London E1 7EZ, England 